\title{
Demonstration and Scaling up of In-Situ Moisture Conservation Techniques on Maize (Zea mays L.) Yield in Negele Arsi and Adami Tulu Jido Kombolcha Districts
}

\author{
Dulo Husen", Zelalem Shalemew, Anbese Ambomsa, Ayub Jelde \\ Oromia Agricultural Research Institute, Adami Tulu Agricultural Research Center, Batu, Ethiopia
}

\section{Email address:}

dulohusen196@gmail.com (D. Husen)

${ }^{*}$ Corresponding author

\section{To cite this article:}

Dulo Husen, Zelalem Shalemew, Anbese Ambomsa, Ayub Jelde. Demonstration and Scaling up of In-Situ Moisture Conservation Techniques on Maize (Zea mays L.) Yield in Negele Arsi and Adami Tulu Jido Kombolcha Districts. Science Research. Vol. 9, No. 1, 2021, pp. 6-13. doi: $10.11648 /$ j.sr.20210901.12

Received: December 11, 2020; Accepted: December 28, 2020; Published: March 10, 2021

\begin{abstract}
The experiment was conducted during 2019 cropping season in six Peasant Associations (PAs) of Negele Arsi and Adami Tulu Jido Kombolcha Districts; with objectives of demonstration and scaling up the selected in-situ moisture conservation structures (Tied ridge and furrow closed at both Ends), awareness creation and analyzed the cost benefit. Totally twelve (12) FREG members were established and 600 farmers, 12 animator and 6 DAs were participated on training from six Peasant Associations (PAs). Two FREG members were established in each Peasant Associations (PAs). From these, 240 farmers were from FREG and 360 from non-FREG were participated on introductory training. Totally 100 farmers, 4 DAs and animator, 4 SMS and 32 others were participated on field day from both districts respectively. The mean yield obtained from tied ridge and furrow closed at both ends were 89.55 and $71.69 \mathrm{Qtha}^{-1}$ at Negele Arsi district and 72.81 and $69.96 \mathrm{Qtha}^{-1}$ were obtained from Adami Tulu Jido Kombolcha district respectively. The two-selected in-situ moisture conservation structures were gave a significant yield in both districts. The net benefit obtained from tied ridge, furrow closed at both end were 50,241 and 37,096 ETH Birr ha ${ }^{-1}$ respectively at NegeleArsi district. In addition, the net benefit obtained from tied ridge and furrow closed at both end were 38,119 and 35,896 ETH Birr ha ${ }^{-1}$ respectively at Adami Tulu Jido Kombolcha district. In-situ moisture conservation structures (tied ridge and furrow closed at both Ends) were more economical and better if it is more scale up in the study area and similar agro ecology. Agricultural and natural resource office should have give a great attention to popularized and scaling up this technologies in moisture deficit areas of the districts.
\end{abstract}

Keywords: Tied Ridge, Furrow Closed at End, FREG, Training, Field Day, Net Benefit, Cost and Yield

\section{Introduction}

Ethiopian semi-arid and arid areas are experiencing low crop yield due to a combination of biophysical problems [7, 8]. Low agricultural productivity in semi-arid region is not only due to land degradation, but also due to moisture deficit [4]. Moisture stress is a prolonged period of short precipitation resulting to water deficiencies and lack of soil moisture to support crop production [17]. Since rainfall is seasonal and erratic in dry lands of Ethiopia and moisture stress limiting the productivity of rain fed agriculture in the moisture stress areas [9]. Moisture stress being the major limitation to crops yield in cereal based cropping systems in
Eastern and Southern Africa [13].

In East Shewa, high moisture deficit is the primary problem, which highly constrains the productivity of small holders' farmers of the districts [11]. In ATJK and NegeleArsi district, onset rainfall variability is the primarily problem to agriculture (raised from farmers). The underlying reason for low crop yield might be the amount and distribution of rainfall is not sufficient to sustain crop growth and development. Hence, an alternative approach is to make use of soil and water conservation structures. Accordingly, crop frequently suffers from moisture stress at some stage during its growth period with the ultimate result of reduced yield in this study area because of shortage or uneven distribution of 
rainfall and lack of awarness on conserving surface runoff within the catchmentand unavailability of in-situ moisture conservation techniques in ATJK and NegeleArsi districts [3].

Unfortunately, most dry spells occur during critical crop growth stages; hence it needs dry spells mitigation by improving water productivity in study areas. This calls to design and scaling up in-situ moisture conservation techniques that have better role in sustaining crop production. Micro catchment is not only raises the yields of specific crops, but also prolongs the effectiveness of crop growing period in the moisture stress area where the crop-growing season is short. Planting crops using in-situ moisture conservation reduces problems of soil moisture stress by reducing runoff through increased infiltration and storage of water in the soil profile. The onset and occurrence of severe water stress is delayed thereby buffering the crop against damage caused by water deficits during dry periods [15]. Therefore, using tied ridge and furrow closed at both end give a solution to the dwindling maize yield production and solving the problem of food insecurity in study areas..

In these regard, using tied ridge and furrow closed at both end are some of the methods that contribute to mitigate soil moisture deficit and enhance maize productivity in the study areas. Currently there is no sufficient research works on demonstrating and scaling up of in-situ moisture conservation techniques on improving maize yield in the study area. The objectives of the experiment was to analyzed the impacts of selected in situ moisture conservation structures on maize yield, cost benefit of the structures and created awareness.

\section{Materials and Methods}

\subsection{Description of Study Area}

The experiment was conducted at Adami Tulu Jido Kombolcha district, which is found in East Shewa zone of Oromia regional state. It is located at a distance of $160 \mathrm{~km}$ from Addis Ababa. Geographically, it is located between $38^{\circ} 25^{\prime} \mathrm{E}$ and $38^{\circ} 55^{\prime} \mathrm{E}$ latitude and $7^{\circ} 35^{\prime} \mathrm{Nand} 8^{\circ} 05^{\prime} \mathrm{N}$ longitude (Figure 1). The elevation of study area is 1636 meters above sea level. In addition, the experiment was conducted in Arsi Negele district, which is found in West Arsi zone of Oromia regional state. It is located at $225 \mathrm{~km}$ south of the Addis Ababa. Geographically, it is situated in the central rift valley system between $7^{\circ} 09^{\prime}-7^{\circ} 41^{\prime} \mathrm{N}$ longitude and $38^{\circ} 25^{\prime}-38^{\circ} 54^{\prime}$ E latitude (Figure 1). The altitude of the study area ranges from 1500 to $2300 \mathrm{~m}$ above sea level and falls in weyna dega Agro-ecological Zone.

\subsection{Climate}

According to the climatic data collected in 2019 from Zeway meteorological station, the total annual rainfall of the area is $627.8 \mathrm{~mm}$ and minimum and maximum temperature is $14.8^{\circ} \mathrm{C}$ and $28^{\circ} \mathrm{C}$ respectively for Adami Tulu Jido kombolcha district. Also the average annual temperature of Negele Arsi district varies from 10 to $25^{\circ} \mathrm{C}$, while the annual rainfall varies between 800 and $1200 \mathrm{~mm}$ [16].

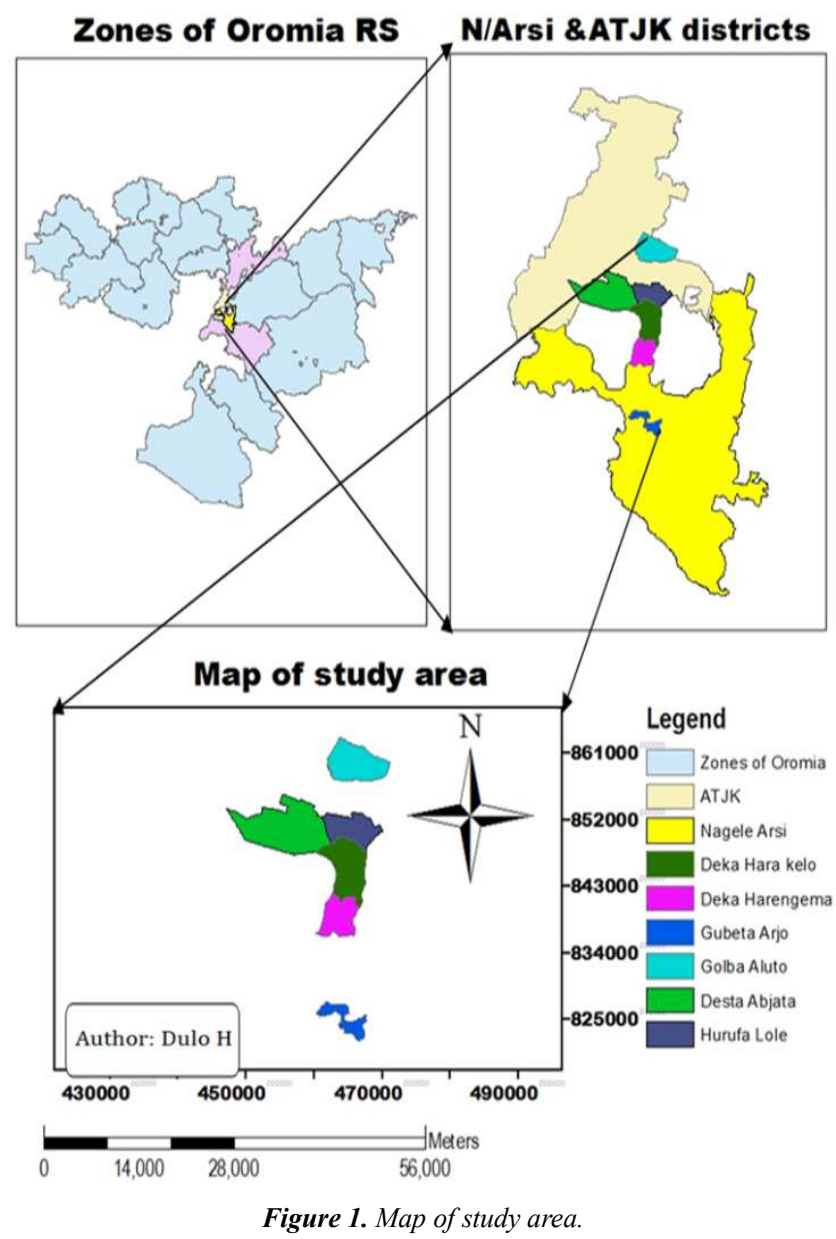

\subsection{Site and Farmer Selection}

The experiment was conducted at three peasant associations (PAs) (Golba Aluto, Desta Abjata, Hurufa Lole) of Adami Tulu Jido Komoblcha district and at three peasant associations (PAs) (Deka Hara kelo, D eka Harengema and Gubeta Arjo) of Negele Arsi district. In each peasant associations (PAs), four farmers were selected and conducted the experiment on their farmland. The peasant associations (PAs) and farmers were selected purposively from Productive Safety Net Program (PSNP) of peasant associations collaboration with district project coordinator, Animators and DAs. From each FREG members, one directly benefited farmer was selected based on his willingness, commitment and interest. The experiment was conducted on the farm size of $50 \mathrm{~m} * 50 \mathrm{~m}\left(2,500 \mathrm{~m}^{2}\right)$ on each farmer. Totally, six hectare (6ha) of land was selected from two districts and conducted the experiment on it. Land preparation was done before construction of in-situ moisture conservation structures on farmland. Two in-situ moisture conservation structures (ridge furrow closed at end and tied ridge) were used for demonstration and scaling up in the study area.

\subsection{Planting Materials, Fertilizer Used and Management}

The BH-540 maize variety used as testing crop and sown 
in row. The recommended fertilizer rate applied for the maize crop. Half of the of UREA and full of the DAP fertilizers were applied at the time of sowing. The second half of the UREA fertilizer was applied 30-40 days after planting during preparation of in-situ moisture conservation structure. All necessary field managements starting from land preparation to harvesting and threshing was conducted.

\subsection{Economic Evaluation}

The total cost required for the experiments were recorded. In addition, total revenues obtained from the experiments were recorded. The recorded grain yield and crop residues were converted to current market price. Then, the profit obtained from the experiments were by subtracting total cost required from total revenues acquired from the experiments. This is as followed by:

$$
\text { Net Befit }(\text { Profit })=T R-T C
$$

Where, $\mathrm{TR}=$ Total Revenue and $\mathrm{TC}=$ Total Cost (Total fixed costs + Total Variable costs)

\subsection{Data Analysis}

The grain and economic data were collected using data collection sheets. Simple financial analysis was employed to analyze the costs required for the experiment and the net benefit gained from the production of each in-situ moisture conservation structures. The data was analyzed using excel and the mean results were presented using tables.

\section{Results and Discussions}

\subsection{Capacity Development}

\subsubsection{FREG Establishments}

The selected farmers were organized under Farmers Research Extension Group (FREG). Totally, twelve (12) FREG numbers were formed and participated in the project (Table 1) in two districts. Two FREG members formed per peasant associations (PAs). Each FREG member holds 20 farmers.

Table 1. FREG establishment and number of FREG.

\begin{tabular}{llll}
\hline Districts & Kebeles & Established FREG & Number of farmers in FREG \\
\hline ATJK & GolbaAluto, DestaAbjata and HurufaLole & 6 & 120 \\
NegeleArsi & GubetaArjo, DekaHarakelo and DekaHarengema & 6 & 120 \\
Total & & 12 & 240 \\
\hline
\end{tabular}

\subsubsection{Training}

Introductory training was organized before imposing any experiment on farmers' field. The farmers, district project coordinators, Animators and DAs from two districts were participated on an introductory training. The training was focused on major limiting factor of study area, in-situ moisture conservation technologies, its impact on increasing maize yield during shortage of rainfall, how the structures were prepared and on which slope of the area it was prepared. Training was organized to orient FREG, Animators and DAs about the technical and related matters of the trial, which was executed. Moreover, training was organized to meet specific gaps on the experiment in the implementation/managing the activity.

One hundred farmers were participated on training per peasant associations (PAs). A total of 600 farmers, 12 animator and 6 DAs were participated on the training (Table 2). From these, 240 farmers fromFREG members and 360 farmers from non FREG members were participated on the training (Table 2 and Figure 2). Training was given on the objectives and target of the activities on in-situ moisture conservation structure and its impact on yield. All FREG and non FREG members were participated on training to obtained theoretical concept. Farmers, Animators, district project coordinatorsand DAs were attended and became aware on the in-situ moisture conservation technologies.
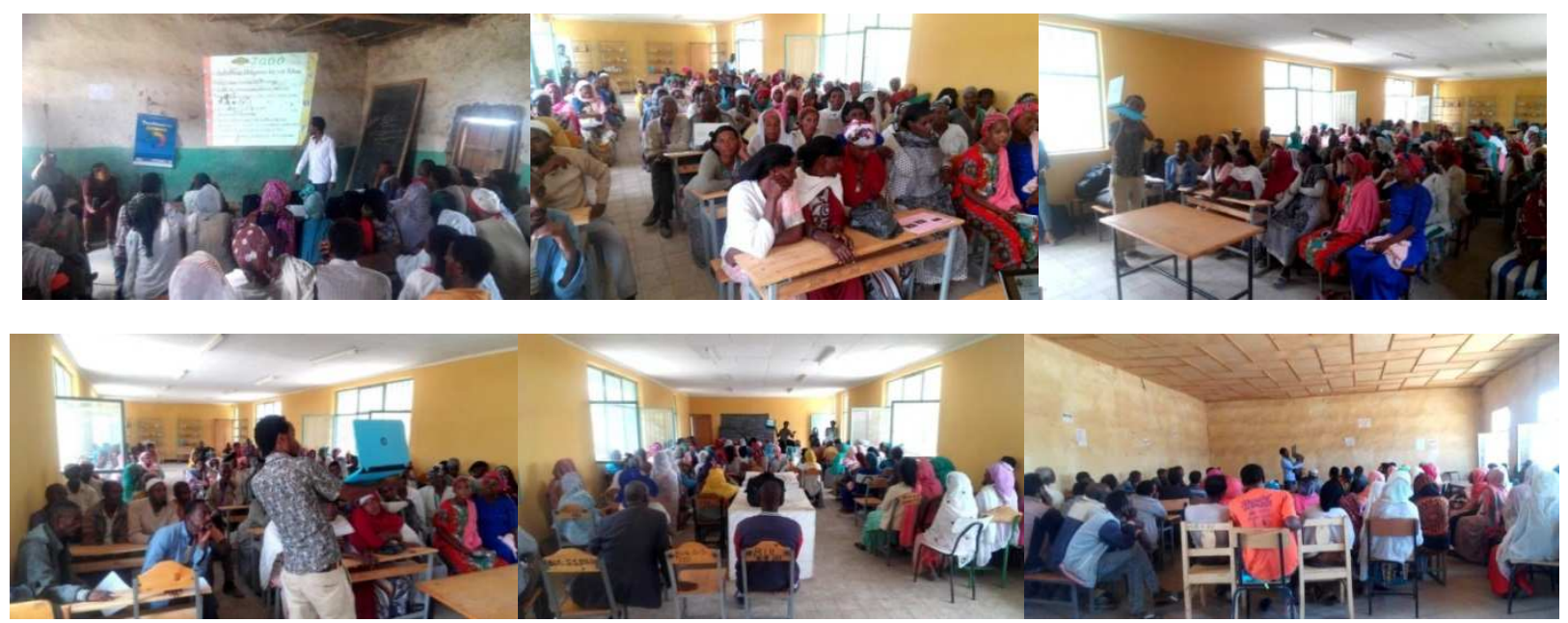


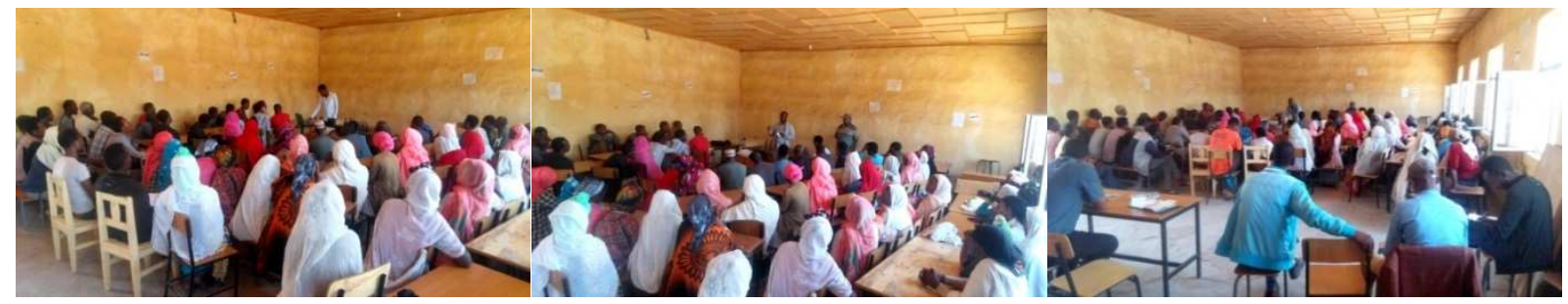

Figure 2. Introductory traininggiven to Farmers, DAs, Animator, SMS and others participants.

Table 2. Numbers of farmers participating on training.

\begin{tabular}{lll}
\hline Districts & Kebeles & Number of farmers participating on training \\
\hline ATJK & GolbaAluto, DestaAbjata and HurufaLole & 300 \\
NegeleArsi & GubetaArjo, DekaHarakelo and DekaHarengema & 300 \\
Total & & 600 \\
\hline
\end{tabular}

\subsubsection{Field Day}

In an attempt to create wider interest and awareness, field day was organized in one peasant association per district. In Adami Tulu Jido Kombolocha (ATJK) and Negele Arsi district) districts, field day was prepared at Golba Aluto and Gubeta Arjo peasant associations respectively. The peasant associations (PAs) were selected purposively based on its accessibility. Famers from Productive Safety Net Program (PSNP), DAs, supervisors, extension team leaders, Animators, Subject matter specialist (SMS) from two districts, researchers and from the team of Meki Catholic Service (MCS) and
Catholic Relief Service (CRS) were participated on the field day by visiting on farm experiment. Atotal of 100 farmers and 40 experts were participated on the field day from two districts.

During field visit, farmers got better opportunity to visited the experiment on field, further asked and discussed on issues which was raised during the training session and helped farmers to got experiences and compare the experiment conducted with in-situ moisture conservation technologies with that of neighboring farmers field. Moreover, from the field day, farmers and experts became aware on the in-situ moisture conservation technologies.
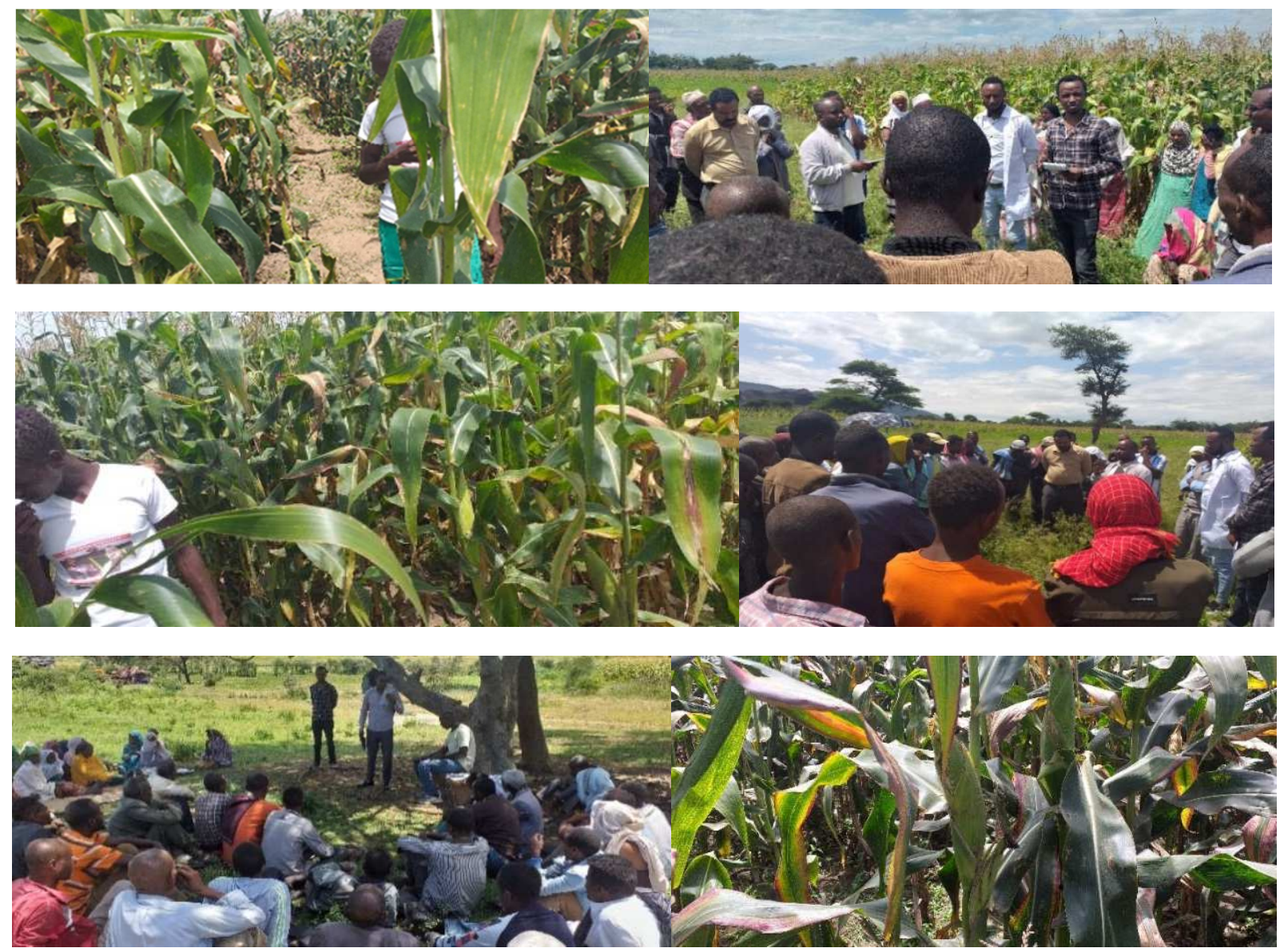


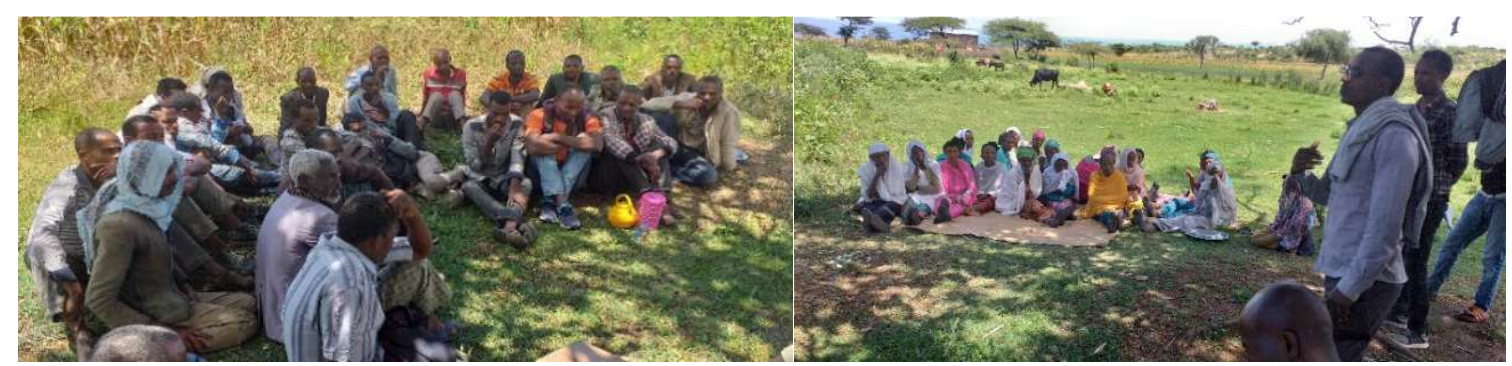

Figure 3. Field day at Negele Arsi (Gubeta Arjo Kebele) and Adami Tulu Jido kombolcha districts (Golba Aluto kebele).

Table 3. Number of farmers, DAs and Animators, SMS and others participated on field day.

\begin{tabular}{lllllll}
\hline \multirow{2}{*}{ Districts } & Peasant association & Farmers & & & \multicolumn{2}{c}{ DAs and animator } \\
\cline { 2 - 6 } & (PA) & Men & Women & Total & Men & Women \\
\hline ATJK & GolbaAluto & 30 & 20 & 50 & 1 & 1 \\
N/Arsi & GubetaArjo & 29 & 21 & 50 & 1 & 1 \\
Total & & 59 & 41 & 100 & 2 & 2 \\
\hline
\end{tabular}

Table 3. Continued.

\begin{tabular}{lllllll}
\hline \multirow{2}{*}{ Districts } & Peasant association & SMS & & & Others & \\
\cline { 2 - 6 } & (PA) & Men & Women & Total & Men & Women \\
\hline ATJK & GolbaAluto & 1 & 1 & 2 & 15 & 1 \\
N/Arsi & GubetaArjo & 1 & 1 & 2 & 15 & 1 \\
Total & & 2 & 2 & 4 & 30 & 2 \\
\hline
\end{tabular}

\subsection{Yield Performances of Selected in Situ Moisture Conservation Structure}

Table 4. Mean yield of maize as affected by tied ridge and furrow closed at both end at NegeleArsi and Adami Tulu Jidokombolcha (ATJK) districts

\begin{tabular}{lllll}
\hline District & Selected treatments & Yield $\left(\mathbf{Q t h a}^{\mathbf{1}}\right)$ & District & Selected treatments \\
\hline NegeleArsi & Tied Ridge & 89.55 & ATJK & Tied Ridge \\
& Furrow closed at both End & 71.69 & & Furrow closed at both End \\
\hline
\end{tabular}

The mean yield obtained from tied ridge and furrow closed at both End were 89.55 and 71.69 Qtha $^{-1}$ respectively at NegeleArsi district (Table 4). In addition, the mean yield obtained from tied ridge and furrow closed at both End were 72.81 and 69.96 Qtha $^{-1}$ respectively at Adami Tulu Jido Kombolcha district (Table 4). The mean yield obtained from tied ridge was better than furrow closed at both ends in the study areas. This might be attributed to tied ridge retaining more moisture when compared to the furrow closed at both end in the study areas. This result agreed with that of tied ridge gave higher yield than furrow closed at both end [3].

In addition, this finding agrees with many researchers, which had reported that the importance of tied ridge is increasing the time for the water to penetrate into the soil and substantial grain yield increase in some of the major dry land crops such as sorghum, maize, wheat, and mung beans in
Ethiopia $[5,6,10,18]$. But, mean yield obtained from furrow closed at both end was better than flat bed practices in the study areas (from farmers interview), and this implied that, it conserve more moisture than flat bed when you compare with neighboring farmer farmland. This result agreed with, the mean yield of maize obtained from furrow closed at both end was higher than flat bed yield [3, 11].

Also, this result agreed with that of tied ridge was harvest more water than flat bed [2]. In-situ water harvesting can increase the moisture in the soil and thus, can result in improved crop yield and have resulted in positive effects on moisture conservation and agricultural productivity [1].

Generally, the experiment results indicated that maize yield was affected by selected in-situ moisture conservation practices. This is apparently due to the moisture conserving benefits of this technologies being critical in drier areas [12].

Table 5. Financial analysis of the experiment at NegeleArsi District.

\begin{tabular}{lll}
\hline Description & Tied Ridge/ha & Furrow Closed at both end/ha \\
\cline { 2 - 3 } & Sub-total (birr) & Sub-total (birr) \\
\hline Total Fixed Costs (TFC) & & \\
Land purchase cost & 4,000 & 4,000 \\
Total Variable Costs (TVC) & & \\
Labor, necessary payment and transport cost & 25,500 & 21,900 \\
Agricultural Input (seed, fertilizer and chemical) & 4,170 & 4,170 \\
Land preparation cost & 1,200 & 1,200 \\
Total Costs (TC) & 34,870 & 31,270 \\
\hline
\end{tabular}


Table 6. Financial analysis of the experiment at Adami Tulu JidoKombolcha (ATJK) District.

\begin{tabular}{lll}
\hline \multirow{2}{*}{ Description } & Tied Ridge/ha & Furrow Closed at both end/ha \\
\cline { 2 - 3 } & Sub-total (birr) & Sub-total (birr) \\
\hline Total Fixed Costs (TFC) & 3,200 & 3,200 \\
Land purchase cost & & \\
Total Variable Costs (TVC) & 22,600 & 20,800 \\
Labor, necessary payment and transport cost & 4,170 & 4,170 \\
Agricultural Input (seed, fertilizer and chemical) & 1,000 & 1,000 \\
Land preparation cost & 30,970 & 29,170 \\
Total Costs (TC) & & \\
\hline
\end{tabular}

\subsection{Financial Analysis}

The total estimated summary cost required for the tied ridge and furrow closed at both end was 34,870 and 31,270 ETH Birr ha $^{-1}$ at Negele Arsi and 30,970, and 29,170 ETH Birr ha ${ }^{-1}$ at Adami Tulu Jido Kombolcha (ATJK) respectively (Tables 5and 6). The tied ridge structure was labor intensive, thus it required more cost than furrow closed at both end.

\subsubsection{Revenue Obtained for the Experiment}

Table 7. Estimated summary Revenue obtained from the tied ridge and furrow closed at end/ha both in ArsiNegele.

\begin{tabular}{lll}
\hline \multirow{2}{*}{ Descriptions } & Revenue from tied ridge/ha & Revenue from Furrow closed at both end/ha \\
\cline { 2 - 3 } & Total (birr) & Total (birr) \\
\hline Yield & 76,118 & 61,166 \\
Crop residual & 9,000 & 7,200 \\
Total & 85,118 & 68,366 \\
\hline
\end{tabular}

Table 8. Estimated summary Revenue obtained from the tied ridge and furrow closed at end/ha both at Adami Tulu JidoKomobolcha (ATJK) District.

\begin{tabular}{lll}
\hline \multirow{2}{*}{ Descriptions } & Revenue from tied ridge/ha & Revenue from Furrow closed at both end/ha \\
\cline { 2 - 3 } & Total (birr) & Total (birr) \\
\hline Yield & 61,889 & 59,466 \\
Crop residual & 7,200 & 6,600 \\
Total & 69,089 & 66,066 \\
\hline
\end{tabular}

From tied ridge, 89.55 and $72.81 \mathrm{Q} \mathrm{tha}^{-1}$ of maize yield was obtained from Arsi Negele and ATJK districts respectively and sold 850 ETH Birr $\mathrm{Qt}^{-1}$ (Table 4). In addition, from furrow closed at end, 71.69 and 69.96 Qt ha ${ }^{-1}$ of maize yield was obtained from Arsi Negele and ATJK districts respectively and sold $850 \mathrm{ETH}$ Birr $\mathrm{Qt}^{-1}$ (Table 4). The estimated revenue of yield and crop residual obtained from tied ridge and furrow closed at both end were 76,118 and 9,000 and 61,166 and 7,200 ETH birr respectively at Negele Arsi district (Table 7). In addition, the estimated revenue of yield and crop residual obtained from tied ridge and furrow closed at both end were 61,889 and 7,200 and 59,466 and 6,600 ETH birr respectively at ATJK district (Table 8). The revenue obtained from tied ridge was better than furrow closed at both end. This implies that, the tied ridge was conserved more moisture than furrow closed at both end and well providing better revenue than furrow closed at both end in both districts. This results agreed with that of revenues of yield and crop residue obtained from tied ridge was better than furrow closed at both end in both districts [11]. The total estimated revenue obtained from the tied ridge and furrow closed at both were 85,118 and 68,366 ETH Birr ha ${ }^{-1}$ at Negele Arsi and 69,089 and 66,066 ETH Birr ha ${ }^{-1}$ at Adami Tulu Jido Kobolcha districts respectively (Tables 7 and 8). The estimated revenues obtained from in-situ moisture conservation was better in Negele Arsi than ATJK distict. This might be a better rainfall and the soil retain more moisture in Negele Arsi than Adami Tulu Jido Kobolcha district.

\subsubsection{Net Benefit}

Net Benefit obtained from the experiment at Negele Arsi

Net Benefit obtained from tied ridge per hectare $=$ Total revenue/ha- total cost/ha

Net Benefit obtained from tied ridge per hectare $=85,118$ 34,870 birr ha $^{-1}=50,248$ ETHBirr ha ${ }^{-1}$

Net Benefit obtained from furrow closed at both end per hectare $=$ Total revenue- Total cost

Net Benefit obtained from furrow closed at both end per hectare $=68,366-31,270$ Birr ha $^{-1}=37,096$ ETH Birr ha ${ }^{-1}$

Net Benefit obtained from the experiment at Adami Tulu Jido Kombolcha (ATJK)

Net Benefit obtained from tied ridge per hectare $=$ Total revenue/ha- total cost/ha

Net Benefit obtained from tied ridge per hectare $=69,089$ 30,970 birr ha ${ }^{-1}=38,119$ ETH Birr ha $^{-1}$

Net Benefit obtained from furrow closed at both end per hectare $=$ Total revenue- Total cost

Net Benefit obtained from furrow closed at both end per hectare $=66,066-29,170 \mathrm{Birr}^{-1}=36,896 \mathrm{ETH} \mathrm{Birr} \mathrm{ha}^{-1}$. 
The total net benefit obtained from tied ridge and furrow closed at both end were 50,241 and 38,119 ETH Birr ha ${ }^{-1}$ in Negele Arsi and ATJK districts respectively. This implies that, the net profit obtained from tied ridge was better than furrow closed at both end in both districts. This result agreed that of the net benefit obtained from tied ridge was better than furrow closed at both end [11]. In addition, this result agreed with the reported of tied ridge has direct effects on crop production and economic benefits over control due to better moisture holding capacity [14]. In addition, total estimated net profit obtained from furrow closed at both end was better than flat bed (from farmers' feedback). This implies that in-situ moisture conservation structure is better in providing better net profit. In generally, the two structures were better in the study in providing better net profit and more economical.

\section{Conclusion and Recommendation}

The low crop productivity in the country particularly in the study area is due to low soil moisture, erratic and poorly distributed rainfall. This calls to design an effective and efficient in-situ moisture conservation strategies. The effect of selected in-situ soil and water conservation measure (tied ridge and furrow closed at both end) was better in terms of maize productivity. The tied ridge structure gave more mean grain yield than furrow closed at both end. Tied ridge and furrow closed at both end showed a promising result on providing maize grain yield.

From the above results, the tied ridge and furrow closed at both end were gave better net benefit. These two structures are more economical and it is better if it is more scale up the study area and similar agro ecology.

Therefore, tied ridge and furrow closed at both end is best for mitigation of low moisture in the study area and similar agro-ecology. As future recommendations, it needs to disseminate the results of the present to end user. Agricultural and natural resource office should be given a great attention to popularized, awareness creation and scaling up of this technologies to overcome problem of moisture deficit and improve land productivity in the study area and similar agro ecology. In addition, the theoretical and practical training should be provided to farmers on in-moisture conservation by schedule.

\section{Conflict of Interests}

The authors have not declared any conflict of interests.

\section{Acknowledgements}

The authors would like to thanks Catholic Relief Services (CRS) for financing the project. In addition, we would like to express his appreciation to all staff of Soil and Water Engineering Research Team of Adami Tulu Agricultural Research Center for their active participation in conducting this experiment. In addition, we would like to grateful to animators, DAs, MCS team and district project coordinators for helped from site and farmers selection up to accomplishing the experiment. Lastly, but not least, we sincerely thanks the farmers who allocated their land for the experiment.

\section{References}

[1] Alemu B and Kidane D. (2014). The Implication of Integrated Watershed Management for Rehabilitation of Degraded Lands Case Study of Ethiopian Highlands. J Agric Biodivers Res, 3 (6): 78-90.

[2] Dagnaw, A., Bagegnehu, B. and Abiy, G. (2018). Onfarm Verification of the Soil Moisture and Yield Response of Tied Ridge on Maize Production in Dry Areas of SNNPR, Ethiopia. Journal of Environment and Earth Science, 8 (5): 1-5.

[3] Dulo Husen, Zelalem Shalemew, Ayub Jelde, Anbase Ambosa and Tesfaye Gemechu (2020). Pre-scaling up of in situ moisture conservation techniques on maize (zea mays 1.) yield in dugda district

[4] Gebreegziabher, T., Nyssen, J., Govaerts, B., Fekadu, G., Mintesinot, B., Mitiku, H., and Deckers, J. (2009). Contour furrows for in situ soil and water conservation, Tigray, Northern Ethiopia. Soil and Tillage Research, 103, 257264.

[5] Gebreyesus B. T., (2004). Tied Ridging as In-situ Rainwater Harvesting Methods for Improving Sorghum Yield at Abergelle Area, Tigray Regional State. An MSc. Thesis submitted to Haremaya University.

[6] Georgis K, Takele A. (2000). Conservation farming technologies for sustaining crop production in semi-arid areas of Ethiopia. In Conservation Tillage for Dryland Farming. Technological options and experiences in Eastern and Southern Africa, eds. E. K. Biamah; J. Rockstrom; G. E. Okwach. RELMA, Workshop Report No. 3, 142-147.

[7] Gicheru P. T., (2002). The effect of different soil management practices on crust formation, soil moisture conservation and crop growth in Machang'a area, Mbeere District, Kenya. Ph. D Thesis. University of Nairobi, Kenya.

[8] Gitau A. N., (2004). Mechanical behavior of hard setting Luvisol soil. Ph. D Thesis, University of Nairobi, Kenya.

[9] Haregeweyn et al., J. Poesen, G. Verstraeten, J. De Vente, G. Govers, S. Deckers, J. Moeyersons, (2005). Specific sediment yield in Tigray, Northern Ethiopia: Assessment and semiquantitative modeling. Geomorphology 69, 315-331.

[10] Heluf G. (2003). Grain yield response of sorghum (sorghum bicolor) to tied ridges and planting methods on Entisols and Vertisols of Alemaya area, Eastern Ethiopian highlands journal of agriculture and rural development in the Tropics and Subtropics 104 (2): 113-128.

[11] Husen, D. and Shalemew, Z (2020). Effects of In-situ Moisture Conservation Techniques on Maize (Zea Mays) Yield and Yield Components (Moisture Deficit Area of Dugda woreda), International Journal of Agricultural] and agribusiness 7 (1): 17-23.

[12] Kassie, M. and Holden, S. (2007). Share cropping efficiency in Ethiopia: threats of eviction and kinship. Agricultural Economics 37: 179-188. 
[13] Mekuria, M. and Waddington, S. (2004) Institutional and Policy Support Is Essential to Promote the Adoption of Soil Fertility Technologies on Maize-Based Smallholder Farms in Southern Africa. Proceedings of the 4th International Crop Science Congress, Brisbane.

[14] Naba, W., Moges, A. and Gebremichael, A. (2020). Evaluating the effect of in-situ rainwater harvesting techniques on maize production in moisture stress areas of humbo woreda, wolaita zone, southern Ethiopia. Int. J. Agril.

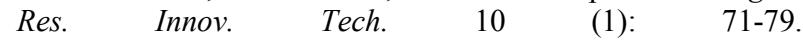
https://doi.org/10.3329/ijarit.v10i1.48096.

[15] Nyamadzawo G, Wuta M, Nyamangara J, Gumbo D. (2013).
Opportunities for optimizing in field water harvesting to cope with changing climate in semi arid smallholder farminga reas of Zimbabwe. Springer plus 2, 1-9.

[16] ORS (2004). The Oromia Regional State government: Socio Economic Profile of East Shoa Zone

[17] Solh, M., \& Van Ginkel, M. (2014). Drought preparedness and drought mitigation in the developing world's drylands. Weather and Climate Extremes, 3 (1), 62-66.

[18] Taye Belachew and YifruAbera, (2010). Response of maize (Zea mays L.) to tied ridges and planting methods at Goro, Southeastern Ethiopia. American-Eurasian Journals ifAgronomy, 3 (1): 21-24. 